\title{
ADSORPTION OF ATRAZINE BY BIOCHARS PRODUCED FROM BYPRODUCTS OF THE WOOD INDUSTRY
}

\author{
Marcelo Fruehwirth ${ }^{*}$, Mariana Sbizzaro ${ }^{1}$, Danielle M. Rosa ${ }^{1}$, \\ Silvio C. Sampaio ${ }^{1}$, Ralpho R. dos Reis ${ }^{1}$
}

${ }^{1 *}$ Corresponding author. Agro-Environmental Sciences Research Group, Western Paraná State University/ Cascavel - PR,
Brazil. E-mail: marcelo_fru@ hotmail.com | ORCID ID: https://orcid.org/0000-0002-8548-3798

\section{KEYWORDS}

water contamination, isotherm, functional groups, kinetics models.

\begin{abstract}
Atrazine is a herbicide widely used in agriculture; however, because of its toxicity, alternatives are needed to remove this compound from the environment. In this study, we investigated the adsorption process and the atrazine-adsorbing ability of three biochars produced at different pyrolysis temperatures from byproducts of the wood industry. The biochars were characterized by Fourier-transform infrared spectroscopy (FTIR) and scanning electron microscopy (SEM), and their physical characteristics were evaluated by Brunauer-Emmett-Teller (BET) analysis. The biochar pyrolyzed at $350{ }^{\circ} \mathrm{C}(\mathrm{BM} 350)$ adsorbed $26.04 \%$ of the herbicide, showing the best performance among the three biochars tested, even though it had the lowest specific surface area $\left(1.467 \mathrm{~m}^{2} \mathrm{~g}^{-1}\right)$. It also had a greater quantity of organic functional groups, which may have influenced the adsorption. The kinetics of the adsorption process were best explained by the pseudofirst-order model and by the Freundlich isotherm model. However, the biochar is not suitable for the removal of the herbicide atrazine, having a lower adsorption capacity than those of others described in the literature.
\end{abstract}

\section{INTRODUCTION}

Atrazine (2-chloro-4-ethylamino-6-isopropylaminos-triazine) is a selective-action herbicide widely used for pest control in maize, sorghum, and sugarcane crops (Mudhoo \& Garg, 2011). Such compounds can be toxic to organisms when disseminated into the environment without proper control (Cleary et al., 2019).

In humans, atrazine is capable of interacting with the endocrine and reproductive systems (Sass \& Colangelo, 2006), and may alter the protein structure of serum albumin (Zhu et al., 2018). In addition, it is classified as potentially carcinogenic by several studies (Donna et al., 1989; Clapp et al., 2007; Komtchou et al., 2019). In nature, research on rats shows problems in the morphology of the male genital system due to contact with atrazine, such as increased estrogen and decreased progesterone levels (Victor-Costa et al., 2010). In addition, several problems have been described in other animals, such as lobsters (Mac Loughlin et al., 2016), fish (Wirbisky \& Freeman, 2017), and amphibians (Gonçalves et al., 2017).
Adsorption is one of the most versatile and effective processes for the removal of contaminants, and when using low-cost adsorbents or industrial wastes, it becomes an economically and environmentally viable alternative (Shaheen et al., 2018). With the increase in the use of plant products by industry, the utilization of byproducts in a sustainable manner has gained more attention (Matos et al., 2013).

The use of byproducts from the wood industry is important for the environment. Some examples include the use of shavings in poultry and pig farms (Sousa et al., 2017), confection of agglomerates with sawdust (Iwakiri, 2005), and the production of biochar, which can be used for the removal of heavy metals and agrochemicals from the environment (Matos et al., 2013).

The properties of the biochar, such as its elemental composition, structure, and chemical stability, depend on the raw material and the pyrolysis temperature. The result can be a porous and fine granular carbon product (Shaheen et al., 2018), with a high specific surface area, which makes

\footnotetext{
${ }^{1}$ Agro-Environmental Sciences Research Group, Western Paraná State University/ Cascavel - PR, Brazil.
} 
it efficient for the adsorption of pesticides (Liu et al., 2015a; Ren et al., 2016).

Considering the benefits of the use of biochar as an adsorbent, and the potential contamination risk of atrazine, the aim of the present study is to evaluate the capacity of three biochars, produced from byproducts of the wood industry at different pyrolysis temperatures, to adsorb the herbicide atrazine in aqueous medium.

\section{MATERIAL AND METHODS}

The biochars used were provided by Embrapa Florestas, located in the Colombo city, state of Paraná, Brazil, made from byproducts of sawmills located in Rio Branco city, state of Acre, Brazil, in the Amazon region, with a pyrolysis temperature of $350{ }^{\circ} \mathrm{C}(\mathrm{BM} 350), 450^{\circ}{ }^{\circ} \mathrm{C}$ (BM450), and $550{ }^{\circ} \mathrm{C}$ (BM550).

A stock solution of atrazine $\left(\mathrm{C}_{8} \mathrm{H}_{14} \mathrm{CIN}_{5}\right.$, SigmaAldrich $\AA$, $99 \%$ purity) in methanol at $500 \mathrm{mg} \mathrm{L}^{-1}$ was prepared.

\section{Characterization of Biochar}

The samples BM350, BM450, and BM550 were ground and sieved to $0.075 \mathrm{~mm}$ for the adsorption and other characterization tests.

The three biochars were also characterized by Fourier-transform infrared spectroscopy (FTIR) using the Thermo ${ }^{\circledR}$ Nicolet $^{\mathrm{TM}}$ IR 200 FT-IR spectrophotometer and following the methodology proposed by Stevenson (1994), by scanning electron microscopy (SEM) using the Tescan ${ }^{\circledR}$ VEGA3 ${ }^{\mathrm{TM}}$ equipment, and for surface area, pore diameter, total pore volume, and volume of micropores by the Brunauer-Emmett-Teller (BET) method using Quantachrome® NovaWin ${ }^{\mathrm{TM}}$ equipment.

\section{Kinetic Tests}

Kinetic adsorption tests were performed in triplicate, in a batch system. In each test, $20 \mathrm{mg}$ of biochars was packed in a $10-\mathrm{mL}$ capped conical tube, and $10 \mathrm{~mL}$ of $4 \mathrm{mg}$ $\mathrm{L}^{-1}$ atrazine solution was added. The mixture was shaken at $180 \mathrm{rpm}$, with the temperature controlled to $22 \pm 0.5{ }^{\circ} \mathrm{C}$. The contact times were 3, 6, 12, 24, 48, 96, 192, 317, 384, 480 , and $576 \mathrm{~h}$. The samples were then centrifuged at 3500 rpm for $15 \mathrm{~min}$, and the supernatant was immediately filtered through a $0.45-\mu \mathrm{m}$ membrane.

The concentration of atrazine in the supernatant was determined by high-performance liquid chromatography using the Chromatograph Shimadzu ${ }^{\circledR}$ Prominence GC2010, according to the methodology proposed by Zheng et al. (2010) and Liu et al. (2015a). The amount of atrazine adsorbed on the biochars in each test was calculated using [eq. (1)]:

$$
\mathrm{Q}_{\mathrm{ad}}=\frac{\left(\mathrm{C}_{\mathrm{i}}-\mathrm{C}_{\mathrm{eq}}\right) \cdot \mathrm{V}}{\mathrm{M}}
$$

Where:

$\mathrm{Q}_{\mathrm{ad}}$ is the amount of atrazine adsorbed per gram of biochar $\left(\mathrm{mg} \mathrm{g}^{-1}\right)$ at time $\mathrm{t}(\mathrm{h})$;

$\mathrm{V}$ is the suspension volume $(\mathrm{L})$;

$\mathrm{C}_{\mathrm{eq}}$ is the atrazine equilibrium concentration $\left(\mathrm{mg} \mathrm{L}^{-1}\right)$;

$\mathrm{C}_{\mathrm{i}}$ is the atrazine initial concentration $\left(\mathrm{mg} \mathrm{L}^{-1}\right)$,

$\mathrm{M}$ is the biochar mass $(\mathrm{g})$.
From the results of the kinetic tests, the mechanisms governing the adsorption process were evaluated using the pseudo-first-order model described in [eq. (2)] and the pseudo-second-order model described in [eq. (3)]:

$$
\begin{aligned}
& \log \left(\mathrm{q}_{\mathrm{e}}-\mathrm{q}_{\mathrm{t}}\right)=\log \mathrm{q}_{\mathrm{e}}-\frac{\mathrm{K}_{1}}{2.303} \mathrm{t} \\
& \frac{\mathrm{t}}{\mathrm{q}_{\mathrm{t}}}=\frac{1}{\mathrm{~K}_{2} \mathrm{qe}^{2}}+\frac{1}{\mathrm{q}_{\mathrm{e}}} \mathrm{t}
\end{aligned}
$$

Where:

$\mathrm{K}_{1}$ is the rate constant of pseudo-first-order adsorption;

$\mathrm{K}_{2}$ is the rate constant of pseudo-second-order adsorption;

$\mathrm{q}_{\mathrm{t}}$ is the amount adsorbed in time $\mathrm{t}\left(\mathrm{mg} \mathrm{g}^{-1}\right)$,

$\mathrm{q}_{\mathrm{e}}$ is the amount adsorbed at equilibrium $\left(\mathrm{mg} \mathrm{g}^{-1}\right)$.

\section{Adsorption Isotherm Tests}

The adsorption tests for the determination of isotherms were performed in triplicate, in a batch system, at concentrations of $2,4,6,8$, and $10 \mathrm{mg} \mathrm{L}^{-1}$. The tests followed the same methodology as that used in the kinetic study. The time of contact, stipulated by the equilibrium point in the kinetic test, was $317 \mathrm{~h}$ for BM450 and BM550 and $480 \mathrm{~h}$ for BM350.

Using the kinetic test results, the Langmuir (1918) and Freundlich (1928) isotherm models were applied. The Langmuir isotherm model was calculated using [eq. (4)], which can be linearized in the form of [eq. (5)]:

$$
\begin{aligned}
& \mathrm{Q}_{\mathrm{ad}}=\frac{\mathrm{K}_{\mathrm{L} \cdot \mathrm{q}_{\text {máx }} \cdot \mathrm{C}_{\mathrm{eq}}}^{1+\mathrm{K}_{\mathrm{L}} \cdot \mathrm{C}_{\mathrm{eq}}}}{\frac{\mathrm{C}_{\mathrm{eq}}}{\mathrm{Q}_{\mathrm{ad}}}=\frac{1}{\mathrm{~K}_{\mathrm{L}} \cdot \mathrm{q}_{\text {máx }}}+\frac{\mathrm{C}_{\mathrm{eq}}}{\mathrm{q}_{\text {máx }}}}
\end{aligned}
$$

Where:

$\mathrm{Q}_{\mathrm{ad}}$ is the amount of atrazine adsorbed on the solid phase $\left(\mathrm{mg} \mathrm{g}^{-1}\right)$;

$\mathrm{K}_{\mathrm{L}}$ is the Langmuir adsorption constant;

$\mathrm{q}_{\max }$ is the maximum cover capacity of the monolayer $\left(\mathrm{mg} \mathrm{g}^{-1}\right)$,

$\mathrm{C}_{\mathrm{eq}}$ is the concentration at equilibrium in the liquid phase $\left(\mathrm{mg} \mathrm{L}^{-1}\right)$.

The Freundlich isotherm model is described by [eq. (6)], which can be linearized in the form of [eq. (7)]:

$$
\begin{aligned}
& \mathrm{Q}_{\mathrm{ad}}=\mathrm{K}_{\mathrm{f}} \cdot \mathrm{C}_{e q}^{\frac{1}{n}} \\
& \ln \mathrm{Q}_{\mathrm{ad}}=\ln \mathrm{K}_{\mathrm{f}}+\frac{1}{n} \ln \mathrm{C}_{\mathrm{eq}}
\end{aligned}
$$

Where:

$\mathrm{C}_{\mathrm{eq}}$ is the concentration at equilibrium in the liquid phase $\left(\mathrm{mg} \mathrm{L}^{-1}\right)$;

$\mathrm{K}_{\mathrm{f}}$ is the Freundlich constant referring to adsorption capacity, and

$n$ is the Freundlich exponent referring to the efficiency of the adsorption process. 
The validity of the models was interpreted by the linearity of the graphs of $\frac{C_{e q}}{Q_{a d}}$ vs. $C_{e q}$ and $\ln Q_{a d}$ vs. $\ln C_{e q}$, respectively.

\section{RESULTS AND DISCUSSION}

\section{Physical and Chemical Properties of the Biochars}

Table 1 shows the physical and chemical properties of the biochars studied. Increasing the pyrolysis temperature increased the carbon content, and, according to Shaheen et al. (2018), the higher the carbon content, the lower the yield in grams of the biochar. It is also possible to observe the reduction in the $\mathrm{O} / \mathrm{C}$ and $\mathrm{H} / \mathrm{C}$ ratios with increasing temperature, revealing the process of carbon structure defunctionalization.

TABLE 1 . Physical and chemical properties of the biochars pyrolyzed at $350{ }^{\circ} \mathrm{C}, 450{ }^{\circ} \mathrm{C}$, and $550{ }^{\circ} \mathrm{C}$.

\begin{tabular}{cccc}
\hline & & Biochar & \\
\cline { 2 - 4 } & BM350 & BM450 & 3.565 \\
SSA $_{\text {BET }}\left(\mathrm{m}^{2} \mathrm{~g}^{-1}\right)$ & 1.467 & 2.438 & 40.01 \\
$\mathrm{P}_{\mathrm{d}}(\AA)$ & 29.08 & 39.51 & 0.013 \\
$\mathrm{P}_{\mathrm{v}}\left(\mathrm{cm}^{3} \mathrm{~g}^{-1}\right)$ & 0.006 & 0.013 & 0.0015 \\
$\mathrm{M}_{\mathrm{V}}\left(\mathrm{cm}^{3} \mathrm{~g}^{-1}\right)$ & 0.0004 & 0.001 & 73.30 \\
$\mathrm{C}(\%)$ & 58.00 & 68.70 & 3.50 \\
$\mathrm{H}(\%)$ & 5.00 & 4.00 & 0.30 \\
$\mathrm{~N}(\%)$ & 0.30 & 0.30 & 23.10 \\
$\mathrm{O}(\%)$ & 36.80 & 27.30 & 0.05 \\
$\mathrm{H} / \mathrm{C}$ & 0.09 & 0.06 & 0.32 \\
$\mathrm{O} / \mathrm{C}$ & 0.63 & 0.40 & 7.70 \\
$\mathrm{pH}$ & 5.80 & 7.00 & 36.90 \\
\hline
\end{tabular}

SSA BET: specific surface area, determined by the BET method; $\mathrm{P}_{\mathrm{d}}$ : mean pore diameter; $\mathrm{P}_{\mathrm{v}}$ : total volume of pores determined in $\mathrm{P} / \mathrm{P}_{0} 0.99$; Mv: micropore volume.

Evaluating the physical characteristics, it was observed that BM350 has a smaller specific surface area than BM450 and BM550. However, the specific surface area is associated with the production temperature, because all organic matter does not tend to degrade at low temperatures (Liu et al., 2015a).

The porosity of the biochars has a strong effect on adsorption, and it appears that most of the pores of the three biochars are in the class of mesopores, but with macropores and micropores also present (Webb \& Orr, 1997).

\section{Fourier-Transform Infrared (FTIR) Spectroscopy}

Owing to the complex composition of the materials, different intensities of FTIR peaks were detected among the biochars. This variety of functional groups directly influences adsorption behavior (Dumanli \& Windle, 2012).

Figure 1 shows the FTIR results for the three biochars. All the biochars have a broad band ranging from 3347 to $2991 \mathrm{~cm}^{-1}$, indicating the presence of hydroxyl groups $(\mathrm{OH})$. This is less pronounced in BM450 and BM550, indicating significant water loss from the materials produced at higher temperatures (Liu et al., 2015a; Liu et al., 2015b). In BM350, peaks are observed in the region between 1545 and $1383 \mathrm{~cm}^{-1}$, corresponding to aromatic C$\mathrm{C}$ and $\mathrm{C}=\mathrm{O}$ bond stretching vibrations, conjugated with ketones and quinones (Liu et al., 2015b). There is also a band at $1290 \mathrm{~cm}^{-1}$, which suggests a group of nitric (NO-) bonding compounds (Yadav, 2005), and two bands in the region from 1207 to $1076 \mathrm{~cm}^{-1}$, the first peak being associated with $\mathrm{C}-\mathrm{H}$ bonds in the aromatic structure of the benzene ring (Szymanski, 2013), and the second peak with primary or secondary alcohol C-O bonds (Keller, 1986). One region of great differentiation between BM350 and the other biochars is the presence in the former of a band at $1026 \mathrm{~cm}^{-1}$, attributed to symmetrical $\mathrm{C}-\mathrm{O}$ stretching, related to cellulose, hemicellulose, and lignin (Liu et al., $2015 \mathrm{~b}$ ), and bands in the region between 910 and $776 \mathrm{~cm}^{-1}$, which can be identified with functional groups of alcoholic $\mathrm{C}-\mathrm{O}$ and with polysaccharide, silicate, and phosphate bonding (He \& Ohno, 2012; Liu et al., 2015b). This difference is the result of incomplete combustion, because biochars produced at lower temperatures tend to preserve their functional groups and structures, which are not found in biochars produced at high temperatures (Liu et al., 2015a). 


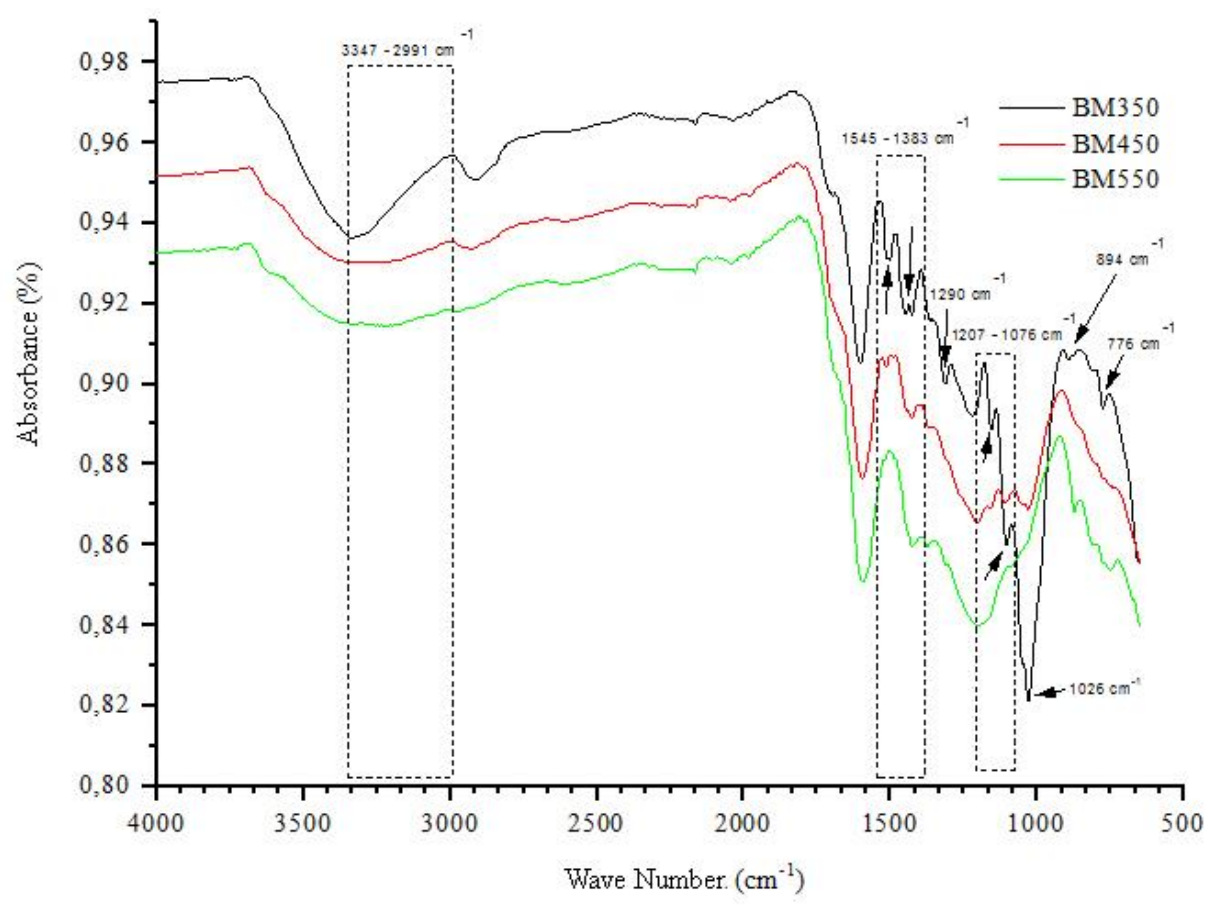

FIGURE 1. Fourier-Transform Infrared (FTIR) spectra for the three biochars

\section{Scanning Electron Microscopy (SEM)}

Figure 2 shows the surface morphologies of the biochars. It is evident that all have an irregular surface, as seen in Figures $2 \mathrm{~A}, 2 \mathrm{~B}$ and $2 \mathrm{C}$.
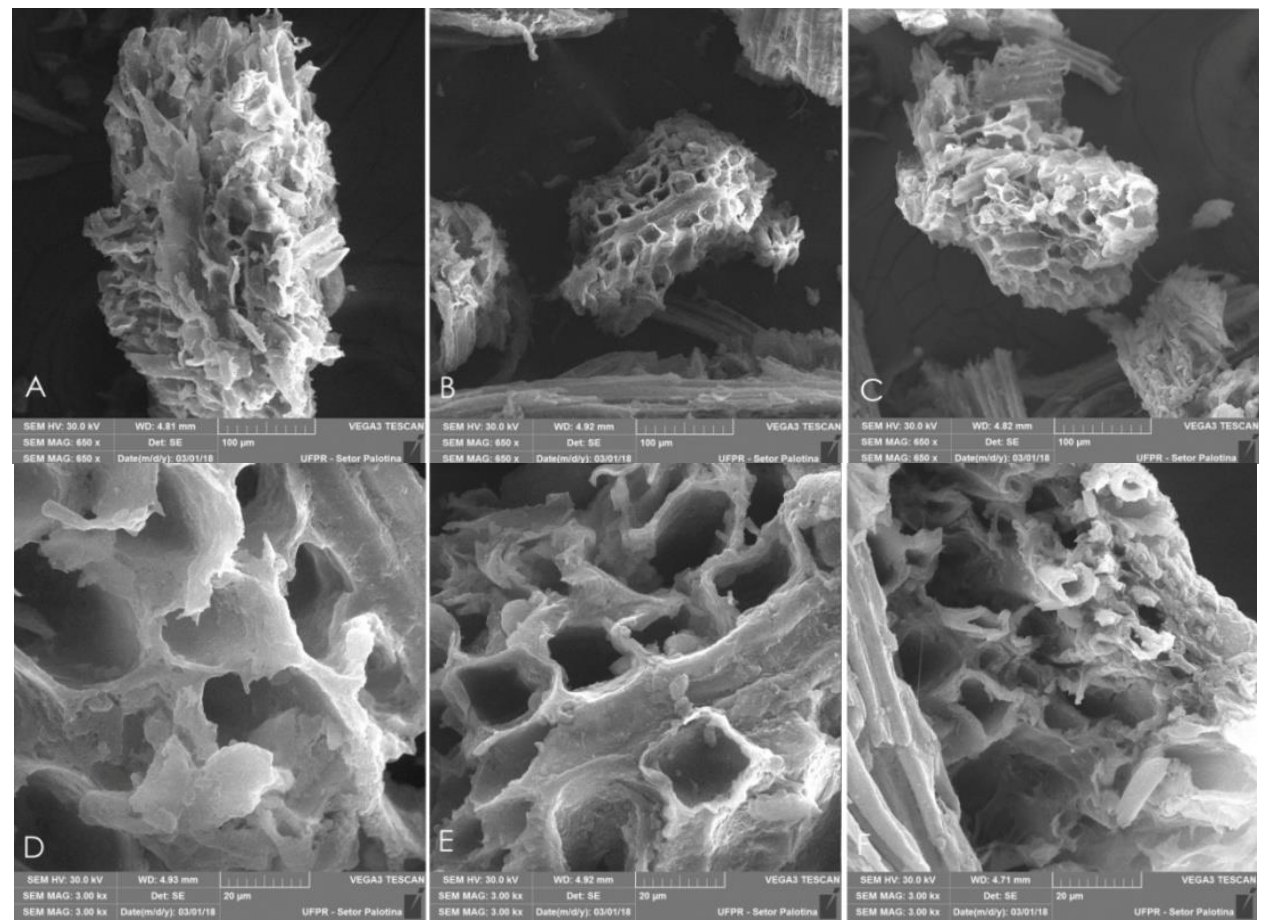

FIGURE 2. Scanning Electron Microscopy. A, B, C: BM350, BM450, and BM550, respectively, at 650x; D, E, F: BM350, BM450, and BM550, respectively, at 3000x

As shown in Figures $2 \mathrm{~A}$ and 2D, the structures are not completely defined, owing to the presence of organic matter (Rehraha et al., 2016). In the images of BM450 and BM550, a better organization, with more clearly defined structures, was observed, evidencing different geometric formations and opening of the pores, as shown in Figures $2 \mathrm{E}$ and $2 \mathrm{~F}$.

\section{Kinetic Study: Determination of the Equilibrium Time of the Adsorption Process}

The adsorption of atrazine in biochars occurs in three phases: (1) an instantaneous adsorption phase, (2) a subsequent slow adsorption phase, and (3) the equilibrium phase (Liu et al., 2015a). Figure 3 shows the amount of atrazine adsorbed as a function of time. It was observed that 
atrazine was adsorbed more slowly in the first $48 \mathrm{~h}$ for BM350, $96 \mathrm{~h}$ for BM450, and $317 \mathrm{~h}$ for BM550, indicating a decrease in the adsorption capacity over time for the biochars, which may be related to gradual blockage of the micropores and mesopores (Patel et al., 2015), and was more evident in BM450 and BM550, which obtained lower responses.

Equilibrium was reached at $480 \mathrm{~h}$ for BM350, with $26.04 \%$ adsorption $\left(\mathrm{Q}_{\mathrm{ad}}=0.529 \mathrm{mg} \mathrm{g}^{-1}\right)$, and at $317 \mathrm{~h}$ for BM450, with $9.73 \%$ adsorption $\left(\mathrm{Q}_{\mathrm{ad}}=0.183 \mathrm{mg} \mathrm{g}^{-1}\right)$, and BM550, with 7.54\% adsorption $\left(\mathrm{Q}_{\mathrm{ad}}=0.145 \mathrm{mg} \mathrm{g}^{-1}\right)$.

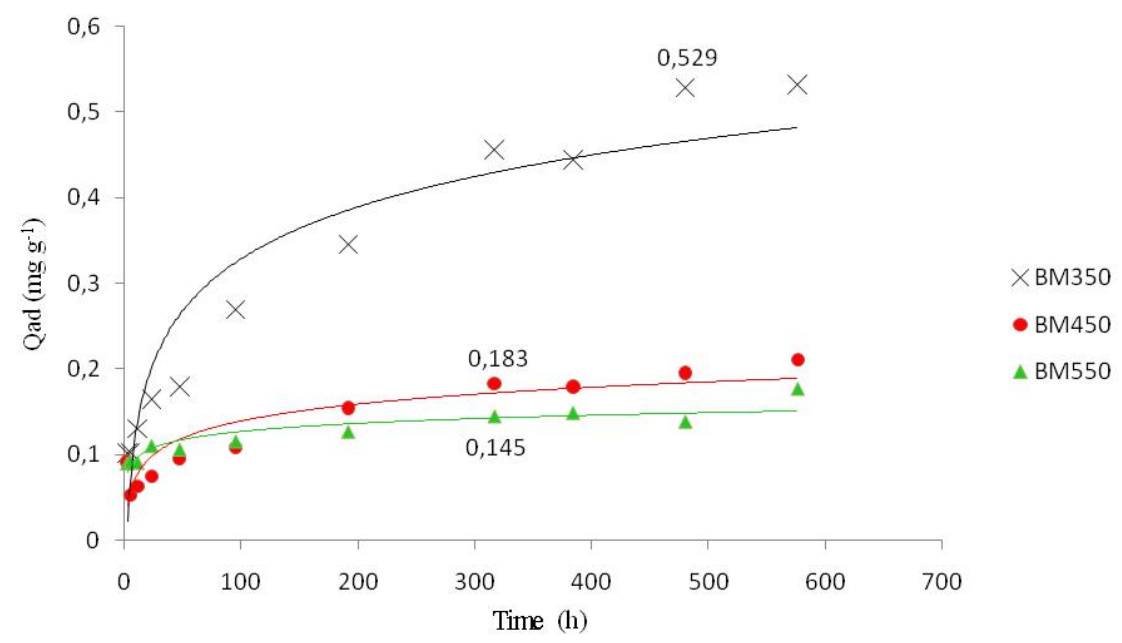

FIGURE 3. Equilibration of atrazine adsorption, at initial concentrations $4 \mathrm{mg} \mathrm{L}^{-1}$

Several studies have shown that the time to reach equilibrium in the adsorption process is affected by the pyrolysis temperature, because of de-functionalization of the carbon structure as well as the presence or absence of organic functional groups (Zheng et al., 2010; Matos et al., 2013; Liu et al., 2015a).

\section{Kinetic Models of Pseudo-First and Pseudo-Second Order}

The pseudo-first- and pseudo-second-order models were evaluated for the three biochars, and the results are presented in Table 2 .

TABLE 2. Kinetic models of pseudo-first and pseudo-second orders.

\begin{tabular}{cccccccccc}
\hline & \multicolumn{3}{c}{ Pseudo-first order } & \multicolumn{5}{c}{ Pseudo-second order } \\
\cline { 2 - 10 } & $\mathrm{q}_{\mathrm{e}}\left(\mathrm{mg} \mathrm{g}^{-1}\right)$ & $\mathrm{K}_{1}$ & $\mathrm{R}^{2}$ & & $\mathrm{q}_{\mathrm{e}}\left(\mathrm{mg} \mathrm{g}^{-1}\right)$ & $\mathrm{K}_{2}$ & $\mathrm{R}^{2}$ & \\
\hline BM350 & 0.424 & 0.0048 & 0.969 & $\mathrm{y}=-0.002 \mathrm{x}-0.372$ & 0.488 & 0.446 & 0.965 & $\mathrm{y}=2.049 \mathrm{x}+94.19$ \\
BM450 & -0.042 & 0.0069 & 0.917 & $\mathrm{y}=-0.003 \mathrm{x}-0.907$ & 0.159 & 0.315 & 0.963 & $\mathrm{y}=6.293 \mathrm{x}+125.6$ \\
BM550 & 0.109 & 0.0046 & 0.905 & $\mathrm{y}=-0.002 \mathrm{x}-1.287$ & 0.127 & 1.671 & 0.997 & $\mathrm{y}=7.835 \mathrm{x}+36.74$ \\
\hline
\end{tabular}

$\mathrm{K}_{1}$ : rate constant of adsorption in pseudo-first order; $\mathrm{K}_{2}$ : rate constant of adsorption in pseudo-second order; qe: calculated quantity adsorbed at equilibrium.

The results revealed that for the biochar produced at $350{ }^{\circ} \mathrm{C}$ (BM350), the kinetics of the adsorption process are best represented by the pseudo-first-order model $\left(\mathrm{R}^{2}=\right.$ 0.969), applied to systems whose model of propulsion forces is linear. The adsorption rate is related to the difference in saturation concentration and the number of adsorbent active sites, indicating that the overall adsorption rate is proportional to the initial strength of the process (Febrianto et al., 2009; Campos et al., 2018).

Kinetic studies revealed that the pseudo-secondorder model provided the best fit to the experimental data for BM450 $\left(\mathrm{R}^{2}=0.963\right)$ and BM550 $\left(\mathrm{R}^{2}=0.997\right)$, suggesting that control of the velocity mechanism is by chemical adsorption, where the overall adsorption rate is proportional to the square of the initial strength of the process (Febrianto et al., 2009), and the molecules bind to the surface of the adsorbent (Gupta \& Suhas, 2009). Thus, the low adsorption observed in these materials can be attributed to the small number of organic functional groups and other compounds present.

\section{Adsorption Isotherms}

Table 3 presents the Langmuir and Freundlich parameters calculated for the three biochars in the atrazine adsorption process to determine the most appropriate isotherms. Using the determination coefficients, it is possible to verify that the model that best describes the process of atrazine adsorption in the biochars studied is the Freundlich model, more clearly in BM350 $\left(\mathrm{R}^{2}=0.998\right)$ than in BM450 $\left(\mathrm{R}^{2}=0.987\right)$ and BM550 $\left(\mathrm{R}^{2}=0.892\right)$. According to Sposito (1989) and Yang et al. (2018), this is associated with the presence of organic matter. 
TABLE 3. Langmuir and Freundlich parameters for adsorption of atrazine.

\begin{tabular}{lllllllll}
\hline & \multicolumn{3}{c}{ Langmuir } & & \multicolumn{3}{c}{ Freundlich } \\
\cline { 2 - 3 } Biochar & $\mathrm{q}_{\text {máx }}\left(\mathrm{mg} \mathrm{g}^{-1}\right)$ & $\mathrm{K}_{\mathrm{L}}$ & $\mathrm{R}^{2}$ & & $\mathrm{~K}_{\mathrm{f}}$ & $n$ & $\mathrm{R}^{2}$ \\
BM350 & 3.333 & 0.057 & 0.983 & & 0.193 & 1.213 & 0.998 \\
BM450 & 0.649 & 0.095 & 0.859 & & 0.070 & 1.513 & 0.987 \\
BM550 & 0.311 & 0.226 & 0.835 & & 0.079 & 2.230 & 0.892 \\
\hline
\end{tabular}

$n$ : dimensionless constant of Freundlich's isotherm model.

Figure 4 shows the equilibrium isotherms for the adsorption of atrazine. It was observed that the amount of atrazine adsorbed was higher in BM350 than in the other biochars. The values of $\mathrm{Q}_{\mathrm{ad}}$ obtained at the end of the process were $1.053 \mathrm{mg} \mathrm{g}^{-1}$ for BM350, $0.321 \mathrm{mg} \mathrm{g}^{-1}$ for BM450, and $0.239 \mathrm{mg} \mathrm{g}^{-1}$ for BM550.

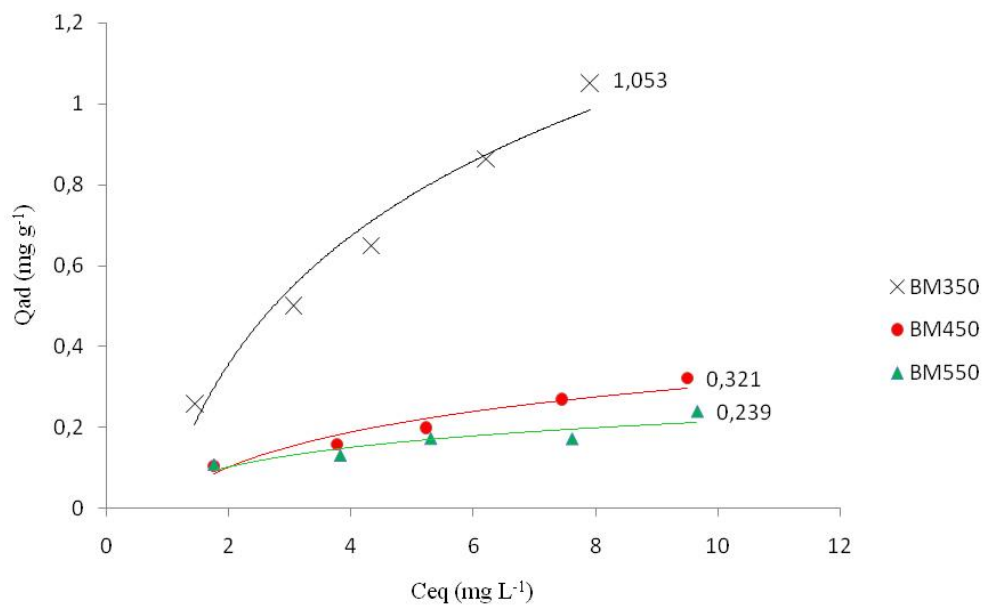

FIGURE 4. Atrazine adsorption isotherms with initial concentrations of 2, 4, 6, 8, and $10 \mathrm{mg} \mathrm{L}^{-1}$ Table 4.

Many studies involving biochars and atrazine are described in the literature, and some of the results are summarized in

TABLE 4. Comparison of the use of biochar for the removal of atrazine.

\begin{tabular}{lcccc}
\hline Raw Material & $\mathrm{T}$ & $\begin{array}{c}\mathrm{SSA}_{\mathrm{BET}}\left(\mathrm{m}^{2} \mathrm{~g}^{-1}\right)^{\mathrm{a}} \\
\mathrm{TSA}_{\text {BET }}\left(\mathrm{m}^{2} \mathrm{~g}^{-1}\right)^{\mathrm{b}}\end{array}$ & $\mathrm{q}_{\mathrm{e}}\left(\mathrm{mg}^{2} \mathrm{~g}^{-1}\right)$ & Reference \\
\hline Acacia decurrens & $350^{\circ} \mathrm{C}$ & $3.902^{\mathrm{a}}$ & 0.430 & Lara (2018) \\
Green waste & $450^{\circ} \mathrm{C}$ & $7.560^{\mathrm{a}}$ & 0.687 & Zheng et al. (2010) \\
Glycine max & $450^{\circ} \mathrm{C}$ & $17.5^{\mathrm{b}}$ & 3.602 & Liu et al. (2015a) \\
Corn straw & $450^{\circ} \mathrm{C}$ & $19.6^{\mathrm{b}}$ & 2.125 & Zhao et al. (2013) \\
Rice husk & $450^{\circ} \mathrm{C}$ & $25.8^{\mathrm{b}}$ & 3.229 & Liu et al. (2015a) \\
Cow excrement & $450^{\circ} \mathrm{C}$ & $13.5^{\mathrm{b}}$ & 2.933 & Liu et al. (2015a) \\
Bird excrement & $450^{\circ} \mathrm{C}$ & $15.4^{\mathrm{b}}$ & 1.990 & Liu et al. (2015a) \\
Pig excrement & $450^{\circ} \mathrm{C}$ & $13.4^{\mathrm{b}}$ & 1.508 & Liu et al. (2015a) \\
By-products of Wood industry & $350^{\circ} \mathrm{C}$ & $1.467^{\mathrm{a}}$ & 0.424 & Present study \\
By-products of Wood industry & $450^{\circ} \mathrm{C}$ & $2.438^{\mathrm{a}}$ & 0.158 & Present study \\
By-products of Wood industry & $550^{\circ} \mathrm{C}$ & $3.565^{\mathrm{a}}$ & 0.127 & Present study
\end{tabular}

$\mathrm{TSA}_{\mathrm{BET}}$ : total surface area determined by BET method.

The efficiency of the process is related to several characteristics (Ren et al., 2016), including the adsorbent raw material, specific surface area, total pore volume, and the presence of organic functional groups (Zheng et al., 2010; Liu et al., 2015a). For adsorbates, the physical characteristics and chemical properties of the molecule should be considered (Song \& Guo, 2012; Ren et al., 2016).
Some authors have correlated the adsorption capacity of biochars with high surface area and mean pore diameter (Zheng et al., 2010; Liu et al., 2015a; Wang et al., 2019) However, this correlation does not apply to this study, because the biochar with the highest adsorptive capacity has the smallest surface area, pore diameter, total pore volume, and micropore volume. 
From the difference between the biochars, mainly demonstrated by the peak at $1026 \mathrm{~cm}^{-1}$ (Figure 1), it is estimated that the presence of organic functional groups may influence the adsorption process (Mudhoo \& Garg, 2011; Kasozi et al., 2012), helping adsorption by the biochar produced at $350{ }^{\circ} \mathrm{C}$, because the influence of organic functional groups on the adsorption is known (Kim et al., 2018). However, the biochars under study were not as effective in adsorbing atrazine as those described in Table 4.

\section{CONCLUSIONS}

Among the biochars produced at the three pyrolysis temperatures studied, the one produced at $350{ }^{\circ} \mathrm{C}$ adsorbed $26.04 \%$ atrazine, and was more efficient than those produced at $450{ }^{\circ} \mathrm{C}$ and $550{ }^{\circ} \mathrm{C}$ due to the influence of organic functional groups on adsorption, explained by the pseudo-first-order model and the Freundlich isotherm model. The adsorptive capacity of the biochars studied was not considered efficient for adsorbing atrazine when compared to other biochars already described in the literature.

\section{ACKNOWLEDGMENTS}

To Embrapa Florestas and Dr. Claudia Maria Branco de Freitas Maia for the biochars, and for elementary and chemical analyses. To CAPES (Coordenação de Aperfeiçoamento de Pessoal de Nível Superior e Tecnológico) and $\mathrm{CNPq}$ (Conselho Nacional de Desenvolvimento Científico e Tecnológico) for financial assistance, and UFPR (Universidade Federal do Paraná Campus Palotina) for the use of equipment for the characterization of biochars.

\section{REFERENCES}

Campos NF, Barros Junior MCG, Cavalcanti JVFL, Barbosa CMBM, Duarte MMMB (2018) Cinética e equilíbrio de adsorção de ácido naftênico em mistura modelo de querosene de aviação utilizando carvão de sabugo de milho como adsorvente. In: Encontro Brasileiro sobre Adsorção. Santa Maria, Universidade Federal de Santa Maria. Anais...

Clapp R, Jacobs MM, Loechler EL (2007) Environmental and Occupational Causes of Cancer - New Evidence, 2005-2007. Lowell Center for Sustainable Production, University of Massachusetts.

Cleary JA, Tillitt DE, vom Saal FS, Nicks DK, Claunch RA, Bhandari RK (2019) Atrazine induced transgenerational reproductive effects in medaka (Oryzias latipes). Environmental Pollution 251:639-650

Donna A, Crosignani P, Robutti F, Betta PG, Bocca R, Mariani N, Ferrario F, Fissi R, Berrino F (1989) Triazine herbicides and ovarian epithelial neoplasms. Scand J Work Environ Health 15(1):47-53

Dumanli AG, Windle AH (2012) Carbon fibres from cellulosic precursors: a review. Journal Mater Science 47:4236-50.
Febrianto J, Kosasih AN, Sunarso J, Ju Y, Indraswati N, Ismadji S (2009) Equilibrium and kinetic studies in adsorption of heavy metals using biosorbent: A summary of recent studies. Journal of Hazardous Materials 162:616-645.

Freundlich H (1928) Colloid and capillary chemistry. New York, E.P. Dutton.

Gonçalves MW, Campos CBM, Batista VG, da Cruz AD, Marco P, Bastos RP, Silva DDE (2017) Genotoxic and mutagenic effects of atrazine Atanor $50 \mathrm{SC}$ on Dendropsophus minutus Peters, 1872 (Anura: Hylidae) developmental larval stages. Chemosphere 182:730-737

Gupta V, Suhas J (2009) Application of low-cost adsorbents for dye removal--a review. J Environ Manage 90(8):2313-42.

He Z, Ohno T (2012) Fourier transform infrared and fluorescence spectral features of organic matter in conventional and organic dairy manure. Journal of Environmental Quality 41:911-919.

Iwakiri S (2005) Painéis de madeira reconstituída. Curitiba, Fundação de Pesquisas Florestais do Paraná, p130-158.

Kasozi GN, Nkedi-Kizza P, Li Y, Zimmerman AR (2012) Sorption of atrazine and ametryn by carbonatic and noncarbonatic soils of varied origin. Environmental Pollution 169:12-19

Keller RJ (1986) FT-IR: The Sigma Library of the FT-IR Spectra. Sigma Chemical Company MO 2:2894.

Kim Y, Jeong D, Park K, Yu JH, Jung S (2018) Efficient Adsorption on Benzoyl and Stearoyl Cellulose to Remove Phenanthrene and Pyrene from Aqueous Solution. Polymers 10(9):1042-55.

Komtchou S, Delegan N, Dirany A, Drogui P, Robert D, El Khakani MA (2019) Photo-electrocatalytic oxidation of atrazine using sputtured deposited TiO2: WN photoanodes under UV/visible light. Catalysis Today. DOI: http://dx.doi.org/10.1016/j.cattod.2019.04.067

Langmuir I (1918) The adsorption of gases on plane surfaces of glass, mica and platinum. Journal of the American Chemical Society 40:1362-1403.

Lara LZ (2018) Avaliação do potencial de produtos de compostagem de dejeitos suínos e de biocarvão ara a remoção do pesticida atrazina em meio aquoso.

Dissertação Mestrado, Porto Alegre, Universidade Federal do Rio Grande do Sul.

Liu N, Charrua BA, Weng CH, Yuan X, Ding F (2015a) Characterization of biochars derived from agriculture wastes and their adsorptive removal of atrazine from aqueous solution: A comparative study. Bioresource Technology 198:55-62.

Liu Y, He Z, Uchimiya M (2015b) Comparison of Biochar Formation from Various Agricultural By-Products Using FTIR Spectroscopy. Canadian Center of Science and Education 9(4):246-253. 
Mac Loughlin C, Canosa IS, Silveyra GR, López Greco LS, Rodriguez EM (2016) Effects of atrazine on growth and sex differentiation, in juveniles of the freshwater crayfish Cherax quadricarinatus. Ecotoxicology Environmental Safety 131:96-103.

Matos TTS, de Jesus AMD, Araújo BR, Romão LPC, Santos LO, Santos JM (2013) Aplicação de Subprodutos Industriais na Remoção de Corantes Reativos Têxteis. Revista Virtual de Química 5(5):840-852.

Mudhoo A, Garg VK (2011) Sorption, transport and transformation of atrazine in soils, minerals and composts. Pedosphere 21:11-25.

Patel S, Han J, Gao W (2015) Sorption of 17b-estradiol from aqueous solutions on to bone char derived from waste cattle bones: Kinetics and isotherms. Journal of Environmental Chemical Engineering 3:1562-1569.

Rehraha D, Bansode RR, Hassanb O, Ahmedna M (2016) Physico-chemical characterization of biochars from solid municipalwaste for use in soil amendment. Journal of Analytical and Applied Pyrolysis 118:42-53.

Ren X, Sun H, Wang F, Cao F (2016) The changes in biochar properties and sorption capacities after being cultured with wheat for 3 months. Chemosphere 144:2257-63.

Sass JB, Colangelo A (2006) European Union bans atrazine, while the United States negotiates continued use. Int. J. Occup. Environ. Health 12:260-267

Shaheen SM, Niazi NK, Hassan NEE, Bibi I, Wang H, Tsang DCW, Ok YS, Bolan N, Rinklebe J (2018) Woodbased biochar for the removal of potentially toxic elements in water and wastewater: a critical review. International Materials Reviews 64(4):1-32.

Song W, Guo M (2012) Quality variations of poultry litter biochar generated at different pyrolysis temperatures. Journal of Analytical and Applied Pyrolysis 94:138-145.

Sousa FC, Tinoco IFF, Silva JN, Baptista F, Souza CF, Silva AL (2017) Gas emission in the poultry production. Journal of Animal Behaviour and Biometeorology 5(2):49-55.
Sposito G (1989) The chemistry of soils. New York, Oxford University Press, 234p.

Stevenson FJ (1994) Humus Chemistry: genesis, composition, reactions. Wiley, New York. 2 ed.

Szymanski HA (2013) Interpreted infrared spectra. New York, Springer, $308 \mathrm{p}$.

Victor-Costa AB, Bandeira SM, Oliveira AG, Mahecha GA, Oliveira CA (2010) Changes in testicular morphology and steroidogenesis in adult rats exposed to Atrazine. Reproductive Toxicology 29(3):323-331

Wang X, Li X, Liu G, He Y, Chen C, Liu X, Li G, Gu Y, Zhao Y (2019) Mixed heavy metal removal from wastewater by using discarded mushroom-stick biochar: adsorption properties and mechanisms. Environmental Science: Processes \& Impacts 21:584-592.

Webb PA, Orr C (1997) Analytical methods in fine particle technology. Norcross, Micromeritics Instrument.

Wirbisky SE, Freeman JL (2017) Atrazine exposure elicits copy number alterations in the zebrafish genome Comp. Biochem. Physiology 194:1-8.

Yadav LDS (2005) Organic spectroscopy. Springer Science \& Business Media 1:82.

Yang F, Gao Y, Sun L, Zhang S, Li J, Zhang Y (2018) Effective sorption of atrazine by biochar colloids and residues derived from different pyrolysis temperatures. Environmental Science and Pollution Research 25(19):18528-39.

Zhao X, Ouyang W, Hao F, Lin C, Wang F, Han S, Geng $X$ (2013) Properties comparison of biochars from corn straw with different pretreatment and sorption behaviour of atrazine. Bioresource Technology 147:338-344.

Zheng W, Guo M, Chow T, Bennett DN, Rajagopalan N (2010) Sorption properties of greenwaste biochar for two triazine pesticides. Journal Hazard Mater 181:121-126.

Zhu M, Wang L, Wang Y, Zhou J, Ding J, Li W, Xin Y, Fan S, Wang Z, Wang Y (2018) Biointeractions of Herbicide Atrazine with Human Serum Albumin: UV-Vis, Fluorescence and Circular Dichroism Approaches. International Journal of Environmental Research and Public Health 15(1):116. 